\title{
IMPLEMENTASI RANCANGAN PEMBELAJARAN BERBASIS TPACK SEBAGAI INTEGRASI PEMBELAJARAN DI ERA SOCIETY 5.0 UNTUK MENINGKATKANHASIL BELAJAR MATA KULIAH EKONOMI KESEHATAN
}

\author{
Imamul Khaira ${ }^{1}$, Evi Susilawati ${ }^{2}$, Refli Renaldi ${ }^{3}$ \\ ${ }^{1,3}$ Universitas Haji Sumatera Utara, ${ }^{2}$ Universitas Islam Sumatera Utara \\ ․ㅡamulkhaira@gmail.com, ${ }^{2}$ evisusilawati@fkip.uisu.ac.id, ${ }^{3}$ reflirenaldi@gmail.com
}

\begin{abstract}
Abstrak: Di Era Society 5.0 seperti sekarang ini, penggunaan teknologi dalam kegiatan pembelajaran menjadi elemen kunci bagi suksesnya proses pembelajaran yang dilakukan dosen di kelasnya. Pembelajaran yang memadukan teknologi dan kemampuan pedagogi dosen yang diselaraskan dengan isi materi pembelajaran yang berkualitas tentunya akan mempengaruhi pengetahuan mahasiswa dalam pencapaian hasil belajar mereka yang maksimal. Oleh karenanya, penelitian ini bertujuan mengimplementasikan rancangan pembelajaran berbasis Technological Pedagogical and Content Knowledge (TPACK) untuk meningkatkan hasil belajar matakuliah Ekonomi Kesehatan. Penelitian ini berbentuk Penelitian Tindakan Kelas dengan mengintegrasikan data penelitain kualitatif dan kuantitatif. Subjek penelitian ini adalah mahasiswa semester III Program Studi Ilmu Kesehatan Masyarakat Fakultas Ilmu Kesehatan Universitas Haji Sumatera Utara pada tahun pelajaran 2021.2. dengan jumlah mahasiswa 17 orang. Data dalam penelitian ini diperoleh dari hasl observasi dosen dalam megimplementasikan rancangan pembelajaran berbasis TPACK, hasl observasi aktivitas belajar mahasiswa dosen dalan mengikuti pembelajaran berbasis TPACK, dan instrumen tes hasil belajar mahasiswa. Temuan penelitian ini menunjukkan bahwa terdapat peningkatan hasil belajar mahasiswa pada mata kuliah Ekonomi Kesehatan dengan mengimplementasikan rancangan pembelajaran berbasis TPACK.
\end{abstract}

Kata Kunci: Rancangan Pembelajaran Berbasis TPACK, Hasil Belajar Matakuliah Ekonomi Kesehatan

\begin{abstract}
In the Era of Society 5.0 as it is today, the use of technology in learning activities is a key element for the success of the learning process carried out by lecturers in their classes. Learning that combines technology and lecturers' pedagogical abilities that are aligned with the content of quality learning materials will certainly affect students' knowledge in achieving their maximum learning achievements. Therefore, this study aims to implement a learning design based on Technological Pedagogical and Content Knowledge (TPACK) to improve learning outcomes for the Health Economics course. This research is in the form of Classroom Action Research by integrating qualitative and quantitative research data. The subjects of this study were third semester students of the Public Health Study Program, Faculty of Health Sciences, Universitas Haji Sumatera Utara in the academic year 2021.2. with 17 students. The data in this study were obtained from the observations of lecturers in implementing TPACK-based learning designs, observations of student learning activities of lecturers in participating in TPACK-based learning, and test instruments for student learning outcomes. The findings of this study indicate that there is an increase in student learning outcomes in the Health Economics course by implementing a TPACK-based learning design.
\end{abstract}

Keywords: TPACK-based Learning Design, Learning Achievements of Health Economics Course

\section{PENDAHULUAN}

Tidak dapat dipungkiri, Era Society 5.0 yang saat ini sedang berlangsung secara global menjadi suatu tanda bahwa manusia telah hidup berdampingan dengan teknologi. Pada Era Society 5.0 ini, seluruh aktivitas masyarakat tidak hanya berpusat pada manusia tetapi juga sudah berbasis pada teknologi (Susilawati \& Khaira, 2021). Kondisi ini menunjukkan bahwa seluruh aktifitas kehidupan manusia selalu bersentuhan dengan teknologi. Demikian juga dalam kegitan pembelajaran di perguruan tinggi.
Tuntutan pembelajaran di Era Society 5.0 ini mengharuskan pembelajaran menggunakan kecanggihan teknologi informasi yang memungkinkan berbagi informasi disajikan dalam kegiatan pembelajaran dengan mudah dan cepat tanpa harus terhambat oleh ruang dan waktu. Oleh karenanya, proses pembelajaran di perguruan tunggi diharapkan dapat berkontribusi pada penguasaan keterampilan yang sesuai dengan perkembangan teknologi dan ilmu pengetahuan (Absari, Priyanto, \& Muslikhin, 2020). Selanjutnya, peran dosen 
bergeser dari pusat pembelajaran ke fasilitator, aspirator, dan motivator yang mana berperan untuk mendukung mahasiswa mencapai prestasi gemilang dalam pembelajaran yang telah dilakukannya. Dosen wajib menyampaikan materi matakuliah dengan benar dan menggunakan teknologi informasi. Selain itu, dosen harus banyak belajar untuk meningkatkan keterampilan dan kompetensi mereka dalam merancang pembelajaran berbasis teknologi informasi dengan menampilkan media pembelajaran yang berbasis konten dan pengetahuan yang berkualitas.

Peran dosen seperti yang telah diuraikan di atas tidak terdapat dalam kegiatan pembelajaran matakuliah Ekonomi Kesehatan di Program Studi Ilmu Kesehatan Masyarakat Fakultas Ilmu Kesehatan Universitas Haji Sumatera Utara. Hasil wawancara dengan beberapa mahasiswa yang menunjukkan bahwa ada kelebihan dan kerugian terhadap keberadaan integrasi teknologi yang sudah dilakukan dalam matakuliah Ekonomi Kesehatan. Kelebihan dari integrasi teknologi ini adalah mahasiswa lebih banyak kreatif dan inovatif dalam memanfaatkan teknologi, tetapi media yang digunakan dosen dalam pembelajaran matakuliah Ekonomi Kesehatan tidak relevan dengan konten pembelajaran.

Pengamatan yang dilakukan terhadap dosen yang mengajar matakuliah Ekonomi Kesehatan menunjukkan bahwa dosen tidak memanfaatkan teknologi secara optimal. Dosen cenderung menggunakan presentasi dalam bentuk power point dalam kegiatan pembelajaran yang mereka lakukan. Dosen tidak dapat menggabungkan konten pengetahuan dan pengetahuan lain yang akan mereka ajarkan. Mereka juga tidak dapat menggabungkan unsur pedagogi dan pengetahuan lain dan menggunakannya secara tepat dalam proses pembelajaran matakuliah Ekonomi Kesehatan.

Mencermati dari beberapa kelemahan proses pembelajaran matakuliah Ekonomi Kesehatan, maka diperlukan kemampuan dosen dalam merancang pembelajaran berbasis TPACK dan mengimplementasikannnya dalam matakuliah Ekonomi Kesehatan dalam rangka memenuhi tuntutan Era Society 5.0. Bagaimanapun, di Era Society 5.0 ini pembelajaran yang dilakukan dosen harus sesuai dengan konten yang sesuai dengan matakuliah yang diajarkan melalui pendekatan pedagogis dan teknologi guna perolehan hasil belajar mahasiswa yang gemilang.

\section{A. Rancangan Pembelajaran Berbasis TPACK}

Paradigma pembelajaran di Era Society 5.0 memerlukan penguasaan konten, pedagogi dan teknologi. Dosen harus memanfaatkan dan menerapkan suatu teknologi informasi dalam proses pembelajaran di kelas mereka. Tantangan belajar terbaru datang dari di Era Society 5.0. Hal ini menuntut dosen untuk memiliki kemampuan menggunakan pembelajaran berbasis Technological Pedagogical and Content Knowledge (TPACK). Pembelajaran berbasis TPACK mengarahkan dosen untuk menguasai pengetahuan tentang bagaimana memfasilitasi mahasiswa belajar dari konten materi pelajaran melalui pendekatan pedagogis dan teknologi (Mansur dkk, 2020). Pembelajaran berbasis TPACK memiliki potensi untuk memberikan arah baru bagi dosen untuk memecahkan masalah yang terkait dengan integrasi Teknologi Komunikasi dan Informasi ke dalam kegiatan belajar mengajar di kelas (Li dkk, 2020).

Kegiatan pembelajaran berbasis TPACK yang mengintegrasikan Teknologi Komunikasi dan Informasi ini sangat tepat diimplementasikan pada matakuliah Ekonomi Kesehatan. Integrasi Teknologi Komunikasi dan Informasi ke dalam kegiatan pembelajaran ini telah memfasilitasi dosen untuk menjawab tantangan pembelajaran di Era Society 5.0 (Dastile, dkk, 2020). Pembelajaran berbasis TPACK ini dikembangkan oleh Koehler \& Mishra (2006) untuk membantu dosen dengan menyediakan kerangka kerja untuk menggambarkan dan menargetkan penggunaan teknologi untuk meningkatkan pembelajaran yang terdiri dari tiga komponen utama yaitu: Pengetahuan Teknologi (TK), Pedagogis Pengetahuan (PK) dan Pengetahuan Konten (CK). Kerangka kerja tersebut dirancang dalam kegiatan pembelajaran matakuliah Ekonomi Kesehatan dengan langkah-langkah sebagai berikut:

1) Kerangka kerja Pedagogical Knowledge $(P K)$ dipahami sebagai Pengetahuan Pedagogi yang menuangkan tentang pengetahuan tentang hakikat belajar matakuliah Ekonomi Kesehatan dengan metode pembelajaran berbasis Teknologi Komunikasi Informasi, pengelolaan kelas, perencanaan pembelajaran, dan penilaian pembelajaran mahasiswa. Pada kegiatan ini 
PK yang implementasikan pada mata kuliah Ekonomi Kesehatan diharapkan mampu meningkatkan kemampuan dosen dalam meramu pembelajaran matakuliah Ekonomi Kesehatan berdasarkan kebutuhan mahasiswa.

2) Kerangka kerja Content Knowledge (CK) merupakan kerangka kerja pengetahuan yang berkaitan dengan materi matakuliah Ekonomi Kesehatan yang diajarkan yang mana dosen matakuliah Ekonomi Kesehatan dapat memahami pelajaran yang akan diajarkan, termasuk pengetahuan tentang fakta, konsep, teori, dan prosedur dalam bidang tertentu, pengetahuan tentang kerangka kerja yang dapat mengorganisasikan dan menghubungkan ide dan pengetahuan tentang aturan, dan bukti konten matakuliah Ekonomi Kesehatan.

3) Kerangka kerja pengetahuan Technological Knowledge (TK) merupakan kerangka kerja keberlanjutan dari PK dan CK dan pengembangan berbasis pengetahuan, termasuk pengetahuan tentang teknologi. Implementasinya dalam pembelajaran matakuliah Ekonomi Kesehatan adalah untuk memproses informasi, berkomunikasi, memecahkan masalah, fokus pada produktif aplikasi yang terintegrasi ke dalam pembelajaran Ekonomi Kesehatan yang dapat memanfaatkan beberapa teknologi yang mendukung pembelajaran Ekonomi Kesehatan. yaitu: laptop dan proyektor (LCD) untuk menampilkan video dalam pembelajaran. Selain itu, dosen dapat menggunakan web untuk membuat pertanyaan terkait untuk matakuliah Ekonomi Kesehatan.

4) Kerangka kerja Pedagogical Content Knowledge (PCK) adalah pengetahuan tentang pedagogi, praktik pembelajaran dan proses perencanaan yang berlaku dan sesuai dengan matakuliah Ekonomi Kesehatan. PCK berkaitan dengan representasi dan perumusan konsep, pedagogis teknik, pengetahuan tentang apa yang membuat suatu konsep sulit atau mudah dipelajari, dan juga pengetahuan tentang pengetahuan dari teori epistemologi mahasiswa sebelumnya.

Langkah-langkah pembelajaran berbasis TPACK pada matakuliah Ekonomi Kesehatan di atas saling terkait satu sama lain. Pembelajaran matakuliah Ekonomi Kesehatan adalah untuk memberikan ruang untuk inovasi sehingga pembelajaran matakuliah Ekonomi Kesehatan ditujukan agar mahasiswa dapat mengembangkan pengetahuan, nilai, sikap, dan keterampilan hidup sehat baik dalam kehidupan bermasyarakat, berbangsa, dan bernegara. Elaborasi TPACK dan dan matakuliah Ekonomi Kesehatan akan memberikan keleluasaan bagi mahasiswa untuk menentukan kecepatan belajar dan memilih urutan kegiatan belajar sesuai dengan kebutuhan mahasiswa yang heterogen yang tentunya akan meningkatkan partisipasi belajar mahasiswa. Implementasi langkahlangkah pembelajaran berbasis TPACK dalam pembelajaran matakuliah Ekonomi Kesehatan diyakini dapat menjadi role model pembelajaran yang berorientasi pada perubahan dan tuntutan Era Society 5.0 dalam merespon era pengetahuan Teknologi Komunikasi dan Informasi.

\section{B. Hasil Belajar Mata Kuliah Ekonomi Kesehatan}

Matakuliah Ekonomi kesehatan merupakan matakuliah yang berisi materi yang menyangkut kegiatan ekonomi dalam bidang kesehatan. Matakuliah ini bertujuan agar mahasiswa dapat memahami dan mengerti tentang fungsi, peran, dan manfaat ekonomi dalam bidang kesehatan. Capaian pembelajatan yang diperoleh mahasiswa setelah mempelajari matakuliah Ekonomi Kesehatan di Program Studi Ilmu Kesehatan Masyarakat Fakultas Ilmu Kesehatan Universitas Haji Sumatera Utara diuraikan sebagai berikut: (1) mahasiswa mampu memahami fitur pendekatan ekonomi untuk menganalisis masalah sosial secara umum, dan untuk menganalisis masalah kesehatan, perawatan kesehatan, dan asuransi kesehatan pada khususnya; (2) mahasiswa mampu mendeskripsikan tren historis dalam pengeluaran perawatan kesehatan dan identifikasi kekuatan mendasar yang mendorong tren tersebut, (3) mahasiswa mampu menyimpulkan faktor-faktor yang mendorong permintaan akan perawatan dalam kesehatan, (4) mahasiswa mampu menyimpulkan konsep kesehatan dan faktor-faktor yang mendorong permintaan akan kesehatan; (5) mahasiswa mampu menemukan solusi dari masalah umum, adverse selection dan moral hazard yang dapat muncul di pasar kesehatan.

Merujuk pada capaian pembelajaran di atas, pentingnya kiranya mendesain model peambelajaran Matakuliah Ekonomi Kesehatan 
yang mampu memberikan wawasan yang berguna kepada mahasiswa tentang bagaimana perawatan kesehatan dapat diatur dan dibiayai dan memberikan kerangka kerja untuk mengatasi berbagai masalah dalam secara eksplisit dan konsisten dan pengaruhnya pada kemampuan perawatan kesehatan dalam pengambilan keputusan. Keberhasilan capaian pembelajaran Matakuliah Ekonomi Kesehatan ini dilihat dari hasil belajar Matakuliah Ekonomi Kesehatan.

Hasil belajar diartikan sebagai hasil dari proses belajar yang dicapai seseorang melalui suatu kegiatan tertentu (Murjianti, dkk, 2018). Di perguruan tinggi, hasil belajar dilihat dari nilai akademik yang didapat oleh mahasiswa. Rafiola, dkk (2020) mengemukakan bahwa hasil belajar sebagai hasil perbuatan membuat penilaian yang dinyatakan dengan angka atau lambang, dimana semua itu menyangkut kemajuan hasil belajar mahasiswa selama periode tertentu. Hasil belajar juga suatu berkaitan dengan seberapa dalam mahasiswa dapat memahami suatu proses pembejalaran. Berdasarkan pada pengertian tersebut, Erpidawati (2019) mengemukakan bahwa hasil belajar merupakan kriteria yang mengukur prestasi siswa dalam hal pengetahuan dan pemahaman terhadap suatu mata kuliah.

Mencermati pendapat-pendapat para ahli mengenai hasil belajar, dapat diberikan pengertian tentang hasil belajar Matakuliah Ekonomi Kesehatan. Adapun yang dimaksud dengan hasil belajar matakuliah Ekonomi kesehatan kemajuan hasil belajar mahasiswa sebagai hasil dari proses belajar Matakuliah Ekonomi Kesehatan yang telah dicapai mahasiswa selama dalam kurun waktu satu semester.

\section{Rancangan Pembelajaran Berbasis TPACK}

Sebagai Integrasi Pembelajaran Di Era Society 5.0 dan Hasil Belajar Matakuliah Ekonomi Kesehatan

Tantangan pembelajaran di Era Society 5.0 adalah adaptasi penggunaan Teknologi Komunikasi dan Informasi untuk memberikan miliaran data pengetahuan kepada siapa saja yang dapat mengaksesnya. Teknologi, Komunikasi dan Informasi membuat orang hidup di dunia di mana pengetahuan dapatbisa diakses oleh siapa saja. Pembelajaran Matakuliah Ekonomi Kesehatan memerlukankan digital ilmiah, dan analisis manajemen kesehatan di Era Society 5.0. Ruang pembelajaran berbasis digitalisasi begitu luas dan mudah. Berbagai pola dan masalah perlu kejelasan untuk dipahami. Kedalaman analisis terhadap materi Matakuliah Ekonomi Kesehatan penting ditentukan oleh dosen sehingga memerlukan perancangan pembelajaran berbasis konten dengan menggunakan metode pedagogis dan teori belajar yang berbasis teknologi.

Kegiatan kegiatan pembelajaran berbasis TPACK ini begitu fleksibel karena dapat dilakukan secara Synchronous dan $A$ synchronous sehingga kegiatan belajar dapat dilakukan dimana saja, kapan saja, dan dengan apa saja. Pembeleajaran berbasis TPACK ini juga dapat dipadupadankan dengan pembelajaran online dan tatap muka yang dibantu dengan Learning Management System $(L M S)$, pembelajaran hibrida, pembelajaran jarak jauh, pembelajaran berbasis web, Semuanya ini memungkinkan terciptanya fleksibilitas dalam mempelajari Matakuliah Ekonomi Kesehatan.. Selanjutnya, pembelajaran berbasis TPACK tidak mengabaikan proses penilaian untuk menilai bagaimana dosen menyampaikan mata pelajaran (pengetahuan pedagogi), penguasaan Matakuliah Ekonomi Kesehatan (pengetahuan isi) dan penguasaan teknologi (technology knowledge); dan untuk memudahkan pengukuran integrasi pencapaian Teknologi Komunikasi Informasi dengan menggabungkan kemampuan yang dimiliki oleh dosen. Kegiatan pembelajaran yang demikian sangat efektif dalam meningkatkan prestasi belajar mahasiswa ( Sahrir dkk, 2021).

\section{METODE PENELITIAN}

Penelitian ini berjenis penelitian tindakan kelas dengan menggunakan Model John Eliot. Desain penelitian dengan menggunakan Model John Eliot ini terdiri atas empat langkah dalam setiap siklusnya. Adapun keempat langkah tersebut diuraikan sebagai berikut: Langkah 1: Perencanaan dengan menyusun rencana pelaksanaan pembelajaran Matakuliah Ekonomi Kesehatan yang akan dilakukan oleh peneliti sebelum melakukan tindakan. Tahapan perencanaan ini dengan membuat rancangan kegiatan pembelajaran Matakuliah Ekonomi Kesehatan yang akan dilakukan dan menyiapkan segala sesuatu yang dibutuhkan dalam penelitianini. Langkah 2: Pelaksanaan dengan 
kegiatan mengimplementasikan pembelajaran berbasis TPACK yang telah disiapkan pada tahap perencanaan Langkah 3. Observasi yang dilakukan oleh tim peneliti dengan mencatat semua kegiatan yang terjadi selama penelitian berlangsung. Langkah 4. Refleksi dengan kegiatan mengkaji secara menyeluruh implementasi pembelajaran berbasis yang telah dilakukan dan melakukan evaluasi untuk menyempurnakan kegiatan pembelajaran selanjutnya. Langkah-langkah kegiatan pembelajaran yang mengimplementasikan rancangan pembelajaran berbasis TPACK dapat dilihat pada Gambar 1. berikut ini:

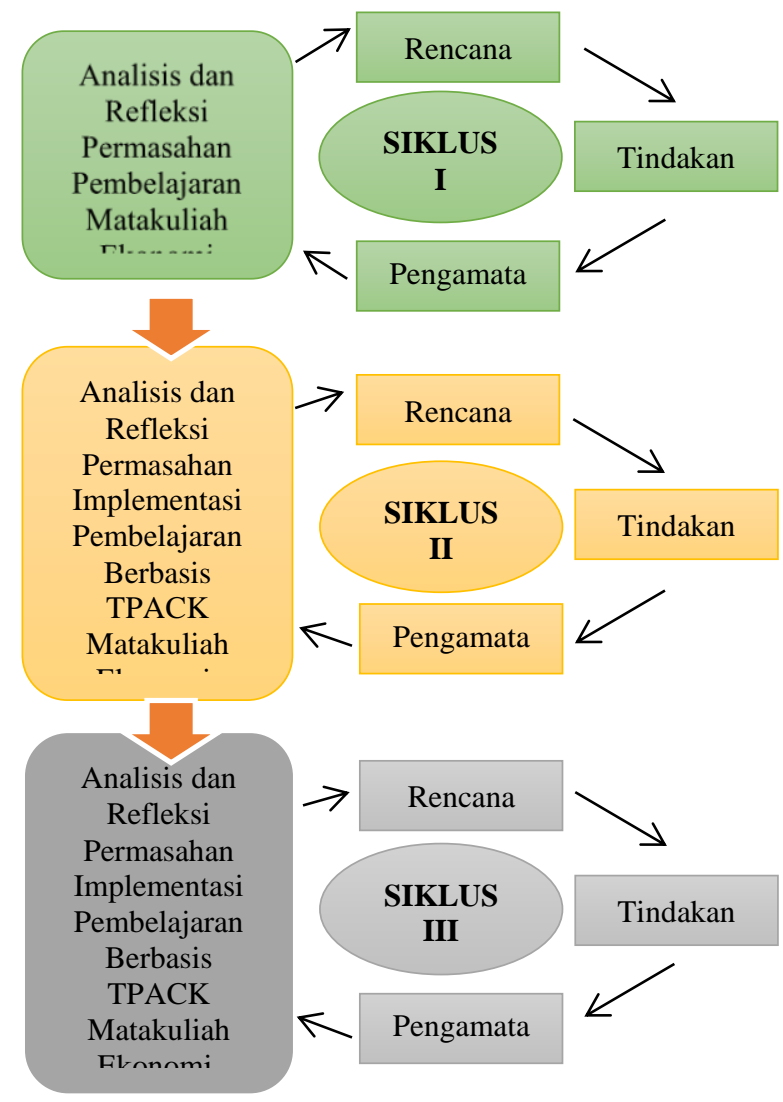

Gambar 1: Langkah-langkah Kegiatan Pembelajaran yang Mengimplementasikan Rancangan pembelajaran berbasis TPACK pada Matakuliah Ekonomi Kesehatan Menurut Model John Eliot

Subjek penelitian ini adalah semester III Program Studi Ilmu Kesehatan Masyarakat Fakultas Ilmu Kesehatan Universitas Haji Sumatera Utara pada tahun pelajaran 2021.2. Pelaksanaan penelitian tindakan kelas ini dilakukan pada Matakuliah Ekonomi Kesehatan dengan jumlah 17 orang. Peran dan posisi peneliti dalam penelitian ini sebagai dosen yang bertindak langsung melakukan kegiatan pembelajaran Matakuliah Ekonomi Kesehatan yang dibantu oleh dua orang observer. Kegiatan penelitian tindakan kelas pada Matakuliah Ekonomi Kesehatan ini dilakukan pada semester ganjil tahun pelajaran 2021.

Pengumpulan data pada penelitian ini menggunakan data kualitatif dan kuantitatif. Penggunaan teknik pengumpulan data pada penelitian ini terdiri dari data kuantitatif dan kualitatif berupa instrumen tes hasil belajar Matakuliah Ekonomi Kesehatan, sementara data diperoleh berdasarkan hasil observasi melalui lembar aktivitas dosen dalam mengimplementasikan pembelajaran berbasis TPACK dan hasil pengamatan terhadap lembar aktivitas mahasiswa dalam mengikuti pembelajaran berbasis TPACK. Lembar observasi aktivitas dosen dapat dilihat pada Tabel 1. berikut ini:

Tabel 1: Lembar Observasi Aktivitas Dosen Implementasikan Rancangan pembelajaran berbasis TPACK pada Matakuliah Ekonomi Kesehatan

\begin{tabular}{|c|c|c|}
\hline No & $\begin{array}{l}\text { Domain } \\
\text { TPACK }\end{array}$ & $\begin{array}{c}\text { Indikator Instrumen } \\
\text { Obesrvasi Aktivitas Dosen }\end{array}$ \\
\hline 1 & TK & $\begin{array}{l}\text { Dosen mengajarkan materi } \\
\text { Matakuliah Ekonomi } \\
\text { Kesehatan dengan } \\
\text { manggunakan teknologi } \\
\text { seperti: Google Forms, } \\
\text { Power Point dan Youtube }\end{array}$ \\
\hline 2 & TPK & $\begin{array}{l}\text { Penggunaan teknologi dalam } \\
\text { strategi pembelajaran } \\
\text { dengan pendekatan } \\
\text { pedagogis, dan pemberian } \\
\text { penilaian berbasis Video } \\
\text { YouTube, Google Forms dan } \\
\text { Diskusi Online }\end{array}$ \\
\hline 3 & TCK & $\begin{array}{l}\text { Dosen memaparkan } \\
\text { relevansi pembelajaran di } \\
\text { Era Society } 5.0 \text { dengan } \\
\text { menggunakan akses } \\
\text { teknologi komunikasi dan } \\
\text { informasi sehingga } \\
\text { mahasiswa dapat belajar } \\
\text { dengan berbagai akses } \\
\text { teknologi komunikasi dan } \\
\text { informasi }\end{array}$ \\
\hline 4 & TPACK & $\begin{array}{l}\text { Dosen menggabungkan } \\
\text { unsur pedagogi, materi } \\
\text { Matakuliah konomi } \\
\text { Kesehatan, dan Teknologi } \\
\text { Komunikasi dan Informasi }\end{array}$ \\
\hline
\end{tabular}




dalam strategi pembelajaran
dengan
konten materi Matakuliah
Ekonomi Kesehatan dengan
mengaitkan latar belakang
serta kemampuan mahasiswa

Aktivitas mahasiswa mengikuti kegiatan pembelajaran berbasis TPACK dapat dilihat dari kegiatan mereka belajar dengan menggunakan Teknologi Komunikasi Informasi yang disesuaikan dengan perkembangan psikis, psikolgis IQ, dan sosial mereka dengan materi dan media pembelajaran Matakuliah Ekonomi Kesehatan, berbasis Teknologi Komunikasi dan Informasi. Lembar observasi aktivitas mahasiswa dapat dilihat pada Tabel 2. berikut ini:

Tabel 2: Lembar Observasi Aktivitas Mahasiswa Belajar Dengan Menggunakan Pembelajaran Berbasis TPACK pada Matakuliah Ekonomi Kesehatan

\begin{tabular}{|c|c|c|}
\hline No & $\begin{array}{l}\text { Domain } \\
\text { TPACK }\end{array}$ & $\begin{array}{c}\text { Indikator Instrumen } \\
\text { Obesrvasi Aktivitas } \\
\text { Mahasiswa }\end{array}$ \\
\hline 1 & TK & $\begin{array}{l}\text { Mahasiswa belajar materi } \\
\text { Matakuliah Ekonomi Kesehatan } \\
\text { dengan manggunakan teknologi } \\
\text { seperti: Google Forms, Power } \\
\text { Point dan Youtube. }\end{array}$ \\
\hline 2 & TPK & $\begin{array}{l}\text { Mahasiswadiajarkan dengan } \\
\text { strategi pembelajaran yang } \\
\text { menggunakan dengan } \\
\text { pendekatan pedagogis, dan } \\
\text { dinilai dengan penilaian } \\
\text { berbasis Video YouTube, } \\
\text { Google Forms dan Diskusi } \\
\text { Online }\end{array}$ \\
\hline 3 & TCK & $\begin{array}{l}\text { Materi Matakuliah Ekonomi } \\
\text { Kesehatan yang diberikan } \\
\text { kepada mahasiswa relevan } \\
\text { dalam kehidupan sehari-hari dan } \\
\text { tuntutan Era Society } 5.0 \text { dengan } \\
\text { menggunakan akses teknologi } \\
\text { komunikasi dan informasi dan } \\
\text { mahasiswa belajar dengan } \\
\text { berbagai akses teknologi } \\
\text { komunikasi dan informasi }\end{array}$ \\
\hline 4 & TPACK & $\begin{array}{l}\text { Mahasiswa belajar berdasarkan } \\
\text { perkembangan psikis, psikolgis, } \\
\text { IQ, dan sosial mereka dengan } \\
\text { materi dan media pembelajaran } \\
\text { Matakuliah Ekonomi } \\
\text { Kesehatan, berbasis Teknologi } \\
\text { Komunikasi dan Informasi }\end{array}$ \\
\hline
\end{tabular}

Untuk instrumen hasil belajar Matakuliah
Ekonomi Kesehatan dalam kegiatan penelitian ini terdiri dari 20 (dua puluh) item soal dalam bentuk Essay Test yang diberikan melalui Google Form. Kisi-Kisi Tes Hasil Belajar Matakuliah Ekonomi Kesehatan dapat dilihat pada Tabel 3. berikut ini:

Tabel 3: Kisi-Kisi Instrumen Hasil Belajar Matakuliah Ekonomi Kesehatan Dengan Menggunakan Pembelajaran Berbasis TPACK pada Matakuliah Ekonomi Kesehatan

\begin{tabular}{|c|c|c|c|}
\hline No & Siklus & Indikator & $\begin{array}{c}\text { Jumlah } \\
\text { Instrum } \\
\text { en }\end{array}$ \\
\hline 1 & Kesatu & $\begin{array}{l}\text { 1) Mahasiswa mampu } \\
\text { memahami fitur } \\
\text { pendekatan } \\
\text { ekonomi untuk } \\
\text { menganalisis } \\
\text { masalah sosial } \\
\text { secara umum, dan } \\
\text { untuk menganalisis } \\
\text { masalah kesehatan, } \\
\text { perawatan } \\
\text { kesehatan, dan } \\
\text { asuransi kesehatan } \\
\text { pada khususnya. } \\
\text { 2) Mahasiswa } \\
\text { mampu } \\
\text { mendeskripsikan } \\
\text { tren historis dalam } \\
\text { pengeluaran } \\
\text { perawatan } \\
\text { kesehatan dan } \\
\text { identifikasi } \\
\text { kekuatan mendasar } \\
\text { yang mendorong } \\
\text { tren tersebut }\end{array}$ & 10 \\
\hline \multirow[t]{2}{*}{2} & \multirow[t]{2}{*}{ Kedua } & $\begin{array}{l}\text { 1) Mahasiswa } \\
\text { mampu } \\
\text { menyimpulkan } \\
\text { faktor-faktor yang } \\
\text { mendorong } \\
\text { permintaan akan } \\
\text { perawatan dalam } \\
\text { kesehatan, }\end{array}$ & 10 \\
\hline & & $\begin{array}{l}\text { 2) Mahasiswa } \\
\text { mampu } \\
\text { menyimpulkan } \\
\text { konsep kesehatan } \\
\text { dan faktor-faktor } \\
\text { yang mendorong } \\
\text { permintaan akan } \\
\text { kesehatan }\end{array}$ & 10 \\
\hline 3 & Ketiga & $\begin{array}{l}\text { Mahasiswa mampu } \\
\text { menemukan solusi }\end{array}$ & 10 \\
\hline
\end{tabular}


dari masalah

umum, adverse

selection dan moral

hazard yang dapat

muncul di pasar

kesehatan.

Indikator keberhasilan dalam kegiatan penelitian tindakan kelas ini baik pada aktivitas dosen, aktivitas mahasiswa, maupun hasil belajarn mahasiswa mpada implementasi pembelajaran berbasis TPACK pada Matakuliah Ekonomi Kesehatan berada pada rentang skor $80 \%-100 \%$.

\section{HASIL DAN PEMBAHASAN}

Hasil Observasi Aktivitas Mengajar Dosen Dalam Mengimplementasikan Rancangan Pembelajaran Berbasis TPACK Sebagai Integrasi Pembelajaran Di Era Society 5.0

Berdasarkan hasil observasi pada aktivitas mengajar dosen dalam mengimplementasikan rancangan pembelajaran berbasis TPACK pada Matakuliah Ekonomi Kesehatan dapat dilihat erolehan skor rata-rata sebesar 54,10, pada siklus II skor rata-rata 75,80 , dan pada siklus III skor rata-rata 83,50. Pencapaian indikator penelitian tindakan kelas pada aktivitas mengajar dosen di siklus III sudah mencapai indikator keberhasilan dalam penelitian ini. Peningkatan aktivitas mengajar dosen dalam mengimplementasikan rancangan pembelajaran berbasis TPACK sebagai integrasi pembelajaran di Era Society 5.0 dapat dilihat pada Tabel 4. Berikut ini:

Tabel 4. Hasil Observasi Aktivitas Mengajar Dosen Dalam Mengimplementasikan Rancangan Pembelajaran Berbasis TPACK Sebagai Integrasi Pembelajaran Di Era Society 5.0

\begin{tabular}{cc}
\hline Siklus & $\begin{array}{c}\text { Rata-Rata Perolehan } \\
\text { Skor }\end{array}$ \\
\hline Siklus 1 & 54,10 \\
\hline Siklus 2 & 75,80 \\
\hline Siklus 3 & 83,50 \\
\hline
\end{tabular}

Hasil Observasi Aktivitas Belajar Mahasiswa Dengan Belajar Berbasis TPACK Sebagai Integrasi Pembelajaran Di Era Society 5.0

Berdasarkan hasil observasi pada aktivitas belajar mahasiswa dalam dalam kegiatan pembelajaran berbasis TPACK pada Matakuliah Ekonomi Kesehatan diperoleh skor rata-rata hasil 53,20, pada siklus II skor rata-rata 71,60, dan pada siklus III skor rata-rata 82,60.
Pencapaian indikator penelitian tindakan kelas pada aktivitas belajar mahasiswa di siklus III sudah mencapai indikator keberhasilan dalam penelitian ini. Peningkatan aktivitas belajar mahasiswa dalam pembelajaran berbasis TPACK sebagai integrasi pembelajaran di Era Society 5.0 dapat dilihat pada Tabel 4. Berikut ini:

Tabel 5. Aktivitas Belajar Mahasiswa Dengan Belajar Berbasis TPACK Sebagai Integrasi Pembelajaran Di Era Society 5.0

\begin{tabular}{cc}
\hline Siklus & $\begin{array}{c}\text { Rata-Rata Perolehan } \\
\text { Skor }\end{array}$ \\
\hline Siklus 1 & 53,20 \\
\hline Siklus 2 & 71,60 \\
\hline Siklus 3 & 82,60 \\
\hline
\end{tabular}

Peningkatan Hasil Belajar Mahasiswa Pada Matakuliah Ekonomi Kesehatan Dengan Menggunakan Rancangan Pembelajaran Berbasis TPACK Sebagai Integrasi Pembelajaran Di Era Society 5.0

Berdasarkan hasil rekapitulasi tes hasil belajar Matakuliah Ekonomi Kesehatan terhadap implementasi rancangan pembelajaran berbasis TPACK pada Matakuliah Ekonomi Kesehatan dapat dilihat perolehan skor rata-rata sebesar 56,60, pada siklus II skor rata-rata 77,30, dan pada siklus III skor rata-rata 85,40 . Pencapaian indikator penelitian tindakan kelas pada aktivitas belajar mahasiswa di siklus III sudah mencapai indikator keberhasilan dalam penelitian ini. Peningkatan aktivitas belajar mahasiswa dalam pembelajaran berbasis TPACK sebagai integrasi pembelajaran di Era Society 5.0 dapat dilihat pada Diagram 1. Berikut ini:

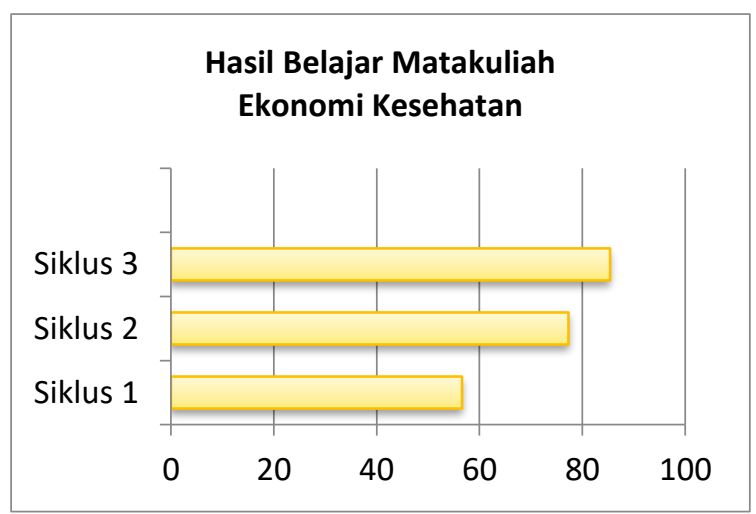

Diagram 1. Peningkatan Hasil Belajar Mahasiswa Pada Matakuliah Ekonomi Kesehatan Dengan Menggunakan Rancangan Pembelajaran Berbasis TPACK Sebagai Integrasi Pembelajaran Di Era Society 5.0 
Mencermati hasil temuan-temuan penelitian di atas dapat dipahami bahwa implementasi rancangan pembelajaran berbasis TPACK sebagai integrasi pembealajran di Era Society 5.0 telah terbukti meningkatkan hasil belajar Matakuliah Ekonomi Kesehatan pada mahasiswa semester III Program Studi Ilmu Kesehatan Masyarakat Fakultas Ilmu Kesehatan Universitas Haji Sumatera Utara. Temuan penelitian ini telah memberikan pengetahuan kepada kita bahwa pembelajaran berbasis TPACK merupakan salah suatu jenis pengetahuan baru yang harus dikuasi dosen untuk dapat mengintegrasikan teknologi dengan baik dalam pembelajaran di Era Society 5.0 ini. Pengukuran TPACK merupakan aktivitas tingkat Temuan penelitian ini sejalan dengan hasil penelitian yang dikemukakan oleh Rahmadi (2019) yang mengemukakan bahwa pembelajaran berbasis TPACK merupakan salah suatu jenis pengetahuan baru yang harus dikuasi pendidik untuk dapat mengintegrasikan teknologi dengan baik dalam pembelajaran, pengukuran TPACK merupakan aktivitas tingkat penguasaan TPACK yang dilakukan menggunakan kerangka kerja TPACK, dan pengembangan TPACK merupakan kelanjutan dari proses pengukuran yang dilakukan untuk meningkatkan penguasaan TPACK. TPACK dapat dijadikan sebagai kerangka kerja untuk mendesain kurikulum pendidikan yang lebih sesuai dengan era dan pembelajaran Era Society 5.0.

Pembelajaran di Era Society 5.0. harus memiliki pengetahuan sekaligus keterampilan dalam menggunakan berbagai perangkat teknologi baik yang tradisional maupun modern untuk memfasilitasi belajar dan meningkatkan hasil pembelajaran. Temuan yang sama juga ditemukan oleh Cahyani, Azizah, dan Evans (2020) dengan implementasi pembelajaran berbasis TPACK pendidik dan peserta didik telah meningkatkan kompetensi mereka dalam menggunakan Teknologi Komunikasi dan Informasi. Dengan banyaknya informasi yang dapat diakses secara online tentang bagaimana mengintegrasikan teknologi dalam pembelajaran dapat meningkatkan hasil belajar mahasiswa. Di Era Society 5.0. saat ini, program pengembangan profesional guru berbasis web semakin banyak dan program pembelajaran khususnya pada Matakuliah Ekonomi Kesehatan semakin menjamur sehingga guru dengan mudah menemukan berbagai materi Matakuliah Ekonomi Kesehatan dan mahasiswa dapat belajar secara mandiri dalam menguasai berbagai materi Matakuliah Ekonomi Kesehatan.

\section{PENUTUP}

Berdasarkan temuan penelitian mengenai implementasi rancangan pembelajaran berbasis TPACK sebagai integrasi pembealajran di Era Society 5.0 terhadap peningkatkan hasil belajar Matakuliah Ekonomi Kesehatan dapat disimpulkan bahwa:

1. Terdapat peningkatan keaktivan dosen dalam menggunakan pembelajaran berbasis TPACK pada siklus I maupun siklus II dengan skor rata-rata sebesar 54,10, pada siklus II skor rata-rata 75,80, dan pada siklus III skor rata-rata 83,50. Perolehan nilai keaktifan dosen dalam meng implementasi rancangan pembelajaran berbasis TPACK sebagai integrasi pembealajran di Era Society 5.0 telah mencapai indikator keberhasilan dalam penelitian ini yang berada pada rentang skor rata-rata 80 .

2. Terdapat peningkatan keaktivan mahasiswa dalam kegiartan pembelajaran berbasis TPACK pada siklus I maupun siklus II dengan skor rata-rata sebesar 53,20, pada siklus II skor rata-rata71,60, dan pada siklus III skor rata-rata 82,60. Perolehan nilai keaktifan dosen dalam meng implementasi rancangan pembelajaran berbasis TPACK sebagai integrasi pembealajran di Era Society 5.0 telah mencapai indikator keberhasilan dalam penelitian ini yang berada pada rentang skor rata-rata 80 .

3. Terdapat peningkatan hasil belajar Matakuliah Ekonomi Kesehatan pada mahasiswa semester III Program Studi Ilmu Kesehatan Masyarakat Fakultas Ilmu Kesehatan Universitas Haji Sumatera Utara pada siklus I maupun siklus II dengan skor rata-rata sebesar 56,60, pada siklus II skor rata-rata77,30, dan pada siklus III skor ratarata 85,40. Perolehan nilai hasil belajar mahasiswa Pada Matakuliah Ekonomi Kesehatan ini telah mencapai indikator keberhasilan dalam penelitian ini yang berada pada rentang skor rata-rata skor 80 .

Berdasarkan pada kesimpulan hasil penelitian yang telah dilaksanan, beberapa saran yang dapat diberikan oleh peneliti sebagai berikut:

1. Dalam proses pembelajaran berbasis TPACK, ada unsur penting yang harus 
diperhatikan yaitu: penerapan media yang berbasis Teknologi Komunikasi dan informasi. Oleh karenanya disarankan bahwa pemilihan media video yang diambil dari You Tube dalam pembelajaran harus memperhatikan pada pemberian manfaat yang besar dalam penyampaian pesan dalam pembelajaran.

2. Pemberian media video yang diambil dari You Tube ataupun yang dibuat sendiri dalam pembelajaran berbasis TPACK harus memperhatikan unsur-unsur yang terdapat dalam media video seperti suara, teks, animasi, dan grafik.

3. Penelitian ini masih memiliki keterbatasan karena relatif kecil jumlah respondenyang dikenai dalam sampel penelitain. . Oleh karena itu, perlu dilakukan penelitian lebih lanjut dengan lebih banyak data dan sampel yang heterogen untuk meningkatkan generalisasi hasil penelitian.

\section{DAFTAR PUSTAKA}

Absari, Nalurita. Priyanto, \& Muslikhin. (2020). The Effectiveness of Technology, Pedagogy, and Content Knowledge (TPACK) in Learning. Jurnal Pendidikan Teknologi dan Kejuruan. Vol. 26, No.1, May 2020. Diakses dari https://doi.org/ 10.21831/jptk.v26i1.24012.

Dastile, Xolani. Dkk. (2020). Statistical and machine learning models in credit scoring: A systematic literature survey. Applied Soft Computing Journal. Volume 91. Diakses dari https://doi.org/10.1016/j.asoc.2020.106 263.

Erpidawati, E., \& Susanti, E. (2019). Kontribusi Pengelolaan Manajemen Kelas Terhadap Hasil Belajar Mahasiswa Fakultas Kesehatan Dan Mipa Universitas Muhammadiyah Sumatera Barat. Jurnal Benefita, 1(1), 70. Diakses dari https://doi.org/10.22216/jbe.v1i1.2405.

Li, Feixue. dkk. (2020). An Agent-Based Learning Embedded Model (ABM Learning) for Urban Land Use Planning: A Case Study of Residential Land Growth Simulation in Shenzhen, China. Land Use Policy. Diakses dari https://ideas.repec.org/a/eee/lauspo/v95y 2020ics0264837719303254.html.

Mishra, P. \& Koehler, M. J. (2006). Technological Pedagogical Content
Knowledge: A Framework for Teacher Knowledge. Teach. Coll. Rec. Vol. 108, No. $6 . \quad$ Diakses dari https://doi.org/10.1111/j.14679620.2006.00684.x.

Mansur, Hamsi.dkk. Teacher's Implementation Capability: The TPACK-Based Curriculum Learning Model with Countenance Evaluation. International Journal of Innovation, Creativity and Change. Volume 13, Issue 4, 2020. Dikases dari www.ijicc.net www.ijicc.net

Murjianti, A., Joebagio, H., \& Suryani, N. (2018). Student Teams Achievement Division with a Learning Video to Increase Students` Achievements and Learning Motivation in Social Science Learning. Yupa: Historical Studies Journal, 2(2), 81-89. Diakses dari https://doi.org/10.30872/yupa.v2i2.119.

Rafiola, R. H., Setyosari, P., Radjah, C. L., \& Ramli, M. (2020). The effect of learning motivation, self-efficacy, and blended learning on students' achievement in the industrial revolution 4.0. International Journal of Emerging Technologies in Learning, 15(8), 71-82. Diakses dari https://doi.org/10.3991/ijet.v15i08.12525.

Rahmadi, Imam Fitri. (2019). Technologycal. Pedagogycal, Content, Knowledge (TPACK). Kerangka Pengetahuan Guru Abad 21. Jurnal Pendidikan Kewarganegaraan. Vol 6. No.1.Maret 2019. Diakses dari http://dx.doi.org/10.32493/jpkn.v6i1.y 2019.p65-74.

Sahrir, Muhammad Sabri. dkk (2021). Employing Technological Pedagogical Content Knowledge (TPACK) Skill Among Teachers in Preparing Online School Assessment for Home-Based Learning. Journal of Arabic Learning. Vol. 4 No. 2 / June 2021. Diakses dari https://doi.org/10.18860/ijazarabi.v4i2.14 93.

Susilawati, Evi. \& Khaira, Imamul. (2021). Peningkatan Kreativitas Mahasiswa

Dalam Merancang Rencana Pembelajaran Berbasis TPACK Sebagai Integrasi Pembelajaran Di Era Society 5.0. E Prosiding Seminar Nasional Pendidikan Pancasila dan Kewarganegaraan 2021. Diakses dari http://C:/SeminarPPKNUNS 